\title{
Creative accounting: some ethical issues of macro- and micro- manipulation
}

\author{
Catherine Gowthorpe \\ Oxford Brookes University \\ Oriol Amat \\ Universitat Pompeu Fabra
}

Key words: Accounting ethics, accounting regulation, creative accounting, earnings management, financial reporting, macro-manipulation, micro-manipulation.

Journal of Economic Literature classification: M41. 


\title{
Creative accounting: some ethical issues of macro- and micro-manipulation
}

\begin{abstract}
This paper examines two principal categories of manipulative behaviour. The term 'macro-manipulation' is used to describe the lobbying of regulators to persuade them to produce regulation that is more favourable to the interests of preparers. 'Micromanipulation' describes the management of accounting figures to poduce a biased view at the entity level. Both categories of manipulation can be viewed as attempts at creativity by financial statement preparers.

The paper analyses two cases of manipulation which are considered in an ethical context. The paper concludes that the manipulations described in it can be regarded as morally reprehensible. They are not fair to users, they involve an unjust exercise of power, and they tend to weaken the authority of accounting regulators.
\end{abstract}




\section{Creative accounting: some ethical issues of macro- and micro-manipulation}

\section{Introduction}

Financial statements provide information that is used by interested parties to assess the performance of managers and to make economic decisions. Users may assume that the financial information they receive is reliable and fit for its purpose. Accounting regulation attempts to ensure that information is produced on a consistent basis in accordance with a set of rules that make it reliable for users. However, communications between entities and shareholders may be deliberately distorted by the activities of financial statement preparers who wish to alter the content of the messages being transmitted. This type of distortion is often referred to as 'creative accounting' or 'earnings management'. While opinions on the acceptability of accounting manipulation vary, it is often perceived as reprehensible.

This paper will try to identify some manipulative behavior on the part of preparers of financial statements, taking into account some important ethical concerns. To achieve this, we will try to broaden out the usual definition of creativity in accounting to examine two principal categories of behaviour by the preparers of financial statements:

-Macro-manipulation: When preparers become aware of a proposal to alter accounting regulation in a way that they feel will be disadvantageous to them, they may engage in lobbying to attempt to prevent the change. They attempt to bring about an alternative depiction of economic reality which is more favourable to them. In this paper we identify this type of behaviour as macro-manipulation.

-Micro-manipulation: Creative accounting at an individual entity level involves preparers in altering accounting disclosures so as to create the view of reality that they wish to have communicated to users of the financial statements. This type of behaviour is described in this paper as micro-manipulation.

In both cases, preparers are interested in creating the financial statements to suit their own purposes. Of course, they may genuinely feel that their view of economic reality is 
preferable from all points of view. However, it is also possible that they seek to distort the picture to meet their own needs. This paper identifies and discusses some significant ethical issues related to these manipulations of accounting reality.

The paper proceeds as follows: first, the principal features of the current accounting regulatory landscape are described. The purpose of regulation, and the objective of financial statements are explained, and the $n$ the paper goes on to discuss the ways in which preparers of financial statements may confound the intentions of the regulators. In the next following section ethical issues of respect, fairness, justice and personal morality are discussed. We then consider two cases of manipulation. The first concerns a case of lobbying over a significant accounting issue in the United States. The second examines some recent evidence from Spain on the manipulation of financial statements that takes place at the entity level. The discussion then moves to re-consideration of the ethical issues identified earlier in the paper.

\section{The accounting regulatory background}

Accounting is regulated in most countries by two principal means: first, local laws relating to corporate and ther bodies, and second, a system of accounting regulation in the form of standards. These are often promulgated by non-governmental organisations and foundations. Also, in recent years, a supra-national body, the International Accounting Standards Committee (IASC) has become more important in setting standards. The IASC came into being in 1973 via an agreement by several leading national professional accountancy bodies. In the period between 1973 and 2001 it grew in status, authority and membership. By 2001 it was poised to become the de facto supranational standard setter for much of the world. A key point was gained with the agreement, in 1995, with the International Organization of Securities Commissions (IOSCO), that the IASC would be responsible for developing a set of 'core standards'. If these were agreed by IOSCO they would be endorsed for use in all global markets. This endorsement took place in 2000. In 2000, the IASC decided to alter its constitution: from 2001 the standard setting body was reconstituted as the International Accounting Standards Board (IASB), to be responsible for issuing International Financial Reporting 
Standards (IFRS). The IASB is currently in the process of addressing some highly complex technical issues that will, in due course, result in the publication of further IFRS. In 2001 the European Commission took the decision to present legislation that required the adoption of international standards by the listed companies of all member states from 2005 onwards. Similar arrange ments will shortly come into operation in Australia and New Zealand ${ }^{\text {ii }}$. It can be expected that several national standard setting bodies around the world will gradually become less important, and may even eventually cease to exist. However, a national standard setter that is likely to exist in the foreseeable future is the Financial Accounting Standards Board (FASB) in the USA. Until recently, it appeared quite possible that US standard setting might proceed autonomously without much regard to the activities of the IASB. However, a convergence project has been launched and it is likely that there will be some significant movement towards convergence over the next few years.

The 'infrastructure of financial reporting'

Schipper (2000) identifies four elements as forming part of 'the infrastructure of financial reporting':

1. The effectiveness of mechanisms for identifying and resolving interpretative questions.

2. The structure, processes, independence, expertise, incentives and resource base of the standards setting organisation.

3. Auditing and auditors.

4. Enforcement of accounting standards and the supporting regulations.

In many national systems, one or more of these elements can be found to be relatively weak (for example, UK accounting regulation was relatively weak in respect of the first and second elements until the early 1990s when the national accounting regulatory system was overhauled). 
Although international accounting regulation can claim to possess the first two of Schipper's (2000) four elements, it is vulnerable in respect of enforcement mechanisms and in respect of auditing and auditors. The IASB has to rely upon national systems and these are likely to be patchy and inconsistent. Fearnley and Macve (2001) identify some of the principal weaknesses preva lent in national systems of compliance: weak support mechanisms for auditors, lack of effective sanctions against directors, and differences between the legal framework and practice. Cairns (2001), summarising the findings of his International Accounting Standards Survey published in 2000, notes a substantial level of non-compliance with international standards amongst companies claiming to adopt them. Current developments in accounting regulation are proceeding rapidly, and the movements towards convergence and even international standardisation are welcomed in many quarters as helping to break down the barriers that hamper the operations of the international capital markets. However, there are some structural weaknesses in accounting regulation. This paper aims to illustrate some of the weaknesses that exist in respect of the role of the preparer, taking into account some important ethical concerns.

\section{The purpose of accounting regulation}

This paper is based in part upon the proposition that accounting regulation has an important function in society. It affects the allocation of economic resources, and so it has potentially wide-ranging effects upon social welfare and the balance of economic power between parties with often competing interests. Prior to the 1970s accounting regulatory bodies were not generally much concerned with the consequential effects of their actions on such matters as distribution and economic well-being. However, from the 1970s onwards, economic impact issues were recognised as being of increasing importance. For example, Zeff (1978) recounts several instances of behaviour on the part of lobbyists that made the Accounting Principles Board in the United States (the predecessor of the current Financial Accounting Standards Board [FASB]) increasingly aware of the impact of its actions. He identifies several factors leading to the recognition of economic consequences as an issue of primary importance, including the following: 
?? A general societal trend towards holding institutions accountable for their actions;

?? The sheer scale of the potential economic impact of accounting regulation;

?? Increasing awareness of the information economics and social choice literature.

The growing awareness of economic impact issues informed the debate that took place in the last 30 years or so of the twentieth century about the establishment of a conceptual framework for accounting. The impetus for the establishment of a conceptual framework started in the USA where the first serious work was done on this type of project. However, conceptual frameworks have subsequently been promulgated elsewhere (for example, in Australia and the United Kingdom and at an international level by the International Accounting Standards Committee [IASC]). The frameworks define the fundamental purpose of financial statements, specify the parties who have a right to take an interest in the products of financial reporting and establish definitions of the key elements of financial accounting, such as assets and liabilities. The objective of financial statements is defined as follows in the Framework for the Preparation and Presentation of Financial Statements published by the IASC in 1989:

"The objective of financial statements is to provide information about the financial position, performa nce and changes in financial position of an enterprise that is useful to a wide range of users in making economic decisions" (paragraph 12).

Accounting regulation, in the form of accounting standards, is based upon this objective which is stated in terms of utility to broadly defined groups in society. It is worth observing, too, that the user groups described in the Framework statement (and the other conceptual framework statements) are extensive in nature, covering investors, employees, lenders, suppliers, customers, governments and the final catch-all of the public. However, priority is awarded to the information needs of investors as the providers of risk capital to business.

So, in summary, financial statements are geared towards decision-making by various different types of user, but the user group of most importance consists of the risk-taking 
investors. Accounting regulators are attuned to the needs of this group in particular, and are concerned with the economic consequences of the standards that they promulgate.

\section{Confounding their policies: preparers versus regulators}

As Zeff (1978) observed, an important factor in accounting regulation is the sheer scale of the economic impact of accounting rules. The choice of an accounting rule may have a very significant impact on, for example, reported profits. The level of profitability of a commercial entity potentially affects distributions to owners, wage and salary negotiations, levels of pensions funding, ability to borrow or to raise further risk capital, taxes paid and so on. The stakes are high, especially in the context of major national or multi-national corporations whose activities have consequential effects on the lives of many people. Regulators may attempt to take the economic consequences of their actions into account, but they are likely to be confounded in many ways. For one thing, the consequences of actions are not always predictable (this is a significant ethical problem in its own right that will be the subject of a separate paper). Another problem, however, and the one with which this paper is concerned, is that when the stakes are high there are considerable incentives for financial statement preparers to confound the work of the regulators.

There are two principal means by which the intentions of the regulators can be confounded by preparers. First, preparers may lobby against proposals for rules that will have an adverse effect upon the financial statements prepared by their entities. Second, where strict application of the rules does not produce an accounting result that meets the needs of preparers, there is an incentive to misapply or to ignore the rule. This condition can pertain only where regulation is weak and/or is inadequately enforced. Both of these means involve manipulation, but the first is at the macro level of policy, and the second at the micro level of the business entity.

The term 'creative accounting' is generally applied to the type of manipulation that takes place at the level of individual business entity. However, we characterise both the macroand micro-activities as creative processes: in both manifestations preparers are busily engaged in managing financial accounting disclosures to their own ends. In both cases 
preparers assert the primacy of their own views of the world and seek to dominate the reporting process with their partisan version of the truth.

\section{Ethical issues in accounting manipulation}

Many ethical ideas suggest themselves in connection with the manipulation of financial reporting. Because the system of accounting regulation shares many features with a system of law, we can look to values and ideas emanating from legal systems and systems of justice. Also, because such systems are societal constructs we can look behind them to issues of individual morality and to fundamental moral values such as truthfulness. Below we briefly explore three ethical issues related to accounting manipulation.

Process values: respect for the law

Lyons (1984) discusses the values that are exemplified in legal processes, and identifies respect for the law as an important element. "For example, well-designed procedures might encourage respect for law, and thus obedience to law, which many believe is a good thing" (p. 196). It may be argued that regulations that can be easily flouted, perhaps because they have been poorly drafted, or because enforcement mechanisms are inadequate, do not command respect. Lyons is discussing the rule of law, but the point applies perhaps with even more force to non-statutory regulation such as accounting regulation. If it fails to command respect from those who are called upon to apply it, then regulatory failure is likely to ensue. In the context of the macro- and micro-manipulation of financial statements that we have identified as problematic in the existing system of accounting regulation, regulation loses authority if it is open to manipulation by a powerful interested party and if it cannot, in any case, be enforced.

Injustice, unfairness and inequality 
Accounting regulators, as we have seen, intend that financial statements should be useful to a wide range of users. The preparers of those financial statements act as intermediaries between the regulators and the users of the statements. They therefore occupy a powerful position as interpreters of the regulations, and, given the complexity of the business world, it is hard to see how some degree of interpretation can be avoided. Some, possibly many, preparers no doubt seek to interpret the regulation fairly and do not attempt to intervene in the regulatory process. However, it is clear that some preparers will adopt any means to hand to assert their own views. This can be seen as a misuse of the authority inherent in their position.

Rawl's (1972) conception of justice as fairness is of value here. In his theory of the social contract, he enunciates two principles of justice. Rawl's second principle is that: "social and economic inequalities are to be arranged so that they are both a) reasonably expected to be to everyone's advantage, and b) attaching to positions and offices open to all". This is not a version of communism: Rawls accepts that the distribution of wealth and income is not, and need not be, equal. However, this principle of justice requires that everyone benefits to some extent, although not necessarily to an equal extent. It would exclude the exercise of power to gain advantage for a particular group such as preparers of financial statements.

This may seem too abstract a notion for application to practical activities such as the promulgation of, and compliance with, accounting standards. However, research evidence does tend to suggest that accounting manipulation is regarded with disapproval by informed professional groups in society such as auditors and accounting practitioners. Fischer and Rosenzweig (1995) found accounting and MBA students to be critical of manipulated transactions and the abuse of accounting rules. Merchant and Rockness (1994) found that accountants were critical of such abuses, and Naser and Pendlebury (1992) discovered similar disapproval amongst UK auditors.

\section{Immorality}

Moving from the general conceptions of injustice and unfairness, we can proceed to a more personal level where individuals make business decisions that may be more or less 
defensible. As Solomon (1993) points out: "We can no longer accept the amoral idea that 'business is business' (not really a tautology but an excuse for being an unfeeling bastard)" (p. 206). Any decisions to lobby from a partisan point of view, or to dress up financial statements, are made by a group of individuals who are themselves moral agents. Business life and decisions are not exempt from considerations of morality. Solomon promotes an Aristotelian approach to business ethics based upon the virtue and good character of the individual.

It is helpful to bear in mind the idea of individual responsibility for wrong actions, and the notion of good character when examining the rather amoral arguments employed to excuse accounting manipulative behaviour. A defence of creative accounting behaviour can be made which rests upon agency and positive accounting theories. Revsine (1991) discusses the 'selective financial misrepresentation hypothesis'. He considers the problem in relation to both managers and shareholders, and argues that each can draw benefits from loosely drafted accounting standards that permit latitude in determining the timing of income. Shareholders can benefit from the fact that managers are able to manipulate earnings to 'smooth' income since this may decrease the apparent volatility of earnings and so increase the value of their shares. The fact that this involves deliberate manipulation and deceit is to be overlooked. Shareholders in this view become unwitting accessories to manipulation, but the agency theoretical supposition is that such behaviour is inevitable given the conflict inherent in agency relationships.

In order to illustrate the nature of the problems identified so far, the next two sections of the paper provide detailed examples of accounting manipulation. The first examines a case of recent successful macro-manipulation in the United States where a highly significant policy decision by the principal accounting regulator was confounded by successful preparer lobbying.

The second case looks at micro-manipulation at the individual accounts level. The case selected for examination is that of Spain, where, as will be seen, quite overt manipulation of earnings figures takes place.

\section{Goodwill accounting in the USA: a case of macro-manipulation}


In July 2001 FASB, the US accounting regulator issued two new standards: FAS Statement no 141 Business combinations and FAS Statement no 142 Goodwill and other intangible assets. FASB had devoted a great deal of time over a five year period to its project on business combinations. The principal concern was the status of pooling of interests (merger) accounting. This is a relatively complex area of accounting, but suffice it to note that pooling of interests generally produces combined statements that show the combination in much better light than under the alternative method of acquisition accounting. The Accounting Principles Board (APB), the predecessor body to FASB, had discussed the issue as early as 1968 with a view to eliminating the use of the pooling method of accounting for combinations. The initial result of the deliberations had been a preliminary recommendation to eliminate the pooling method altogether, but the APB was persuaded to retreat from this hard line position (according to Zeff (1978) the APB appeared "almost as a pawn in a game of political chess....as it abandoned positions of principle in favor of an embarrassing series of pressure-induced compromises". (p. 59)). APB Statement No 16 instead established a set of 12 restrictive criteria to be met before the pooling method could be adopted. Although APB Statement No 16 restricted the use of the pooling method, according to Ayers et al. (2000), subsequent research suggested that “... managers prefer this accounting method and are willing to incur significant costs to avoid the recognition of additional assets and expenses associated with the purchase method" (p. 2).

Pooling has been heavily used: one recent estimate is that in 1998 around of 55\% of new business combinations (out of a total of 11,400 transactions) were accounted for under the pooling method (Ayers et al. 2000). FASB's concerns about the issue included the following:

?? The issue of comparability between groups of companies

?? The heavy utilisation of regulatory resources upon the results of this method of accounting (FASB and SEC staff were spending 'considerable time' interpreting financial statements produced under the pooling method).

?? The underlying substance of genuine pooling is rarely encountered in practice. 
FASB therefore proposed, via an exposure draft issued in 1999, that the pooling method be completely outlawed, a proposal which was eventually to form a significant part of SFAS 141. Ayers et al. (2000), writing before the issue of the standard itself, had estimated, based upon examination of many transactions accounted for by the pooling method, that the elimination of the pooling method in US accounting would have significant economic consequences in that, for example, earnings per share and return on equity would deteriorate.

The worsening of key ratios which results from recording combinations via the purchase method no doubt had much to do with corporate America's reluctance to accept the elimination of the pooling method. The technology company Cisco (2000), a significant lobbyist against FASB's proposals, provided the following list of dire consequences ${ }^{\mathrm{iii}}$ which could follow FASB's standard:

?? Impeding of innovation and investment in new technologies;

?? Slowing of overall economic growth of high-tech companies

?? Significant reduction in merger \& acquisition activity

?? Impact on shareholder value and artificial reduction in corporate earnings

?? Reduction in the number of small enterpreneurial companies able to develop or compete with established companies.

One of the technical accounting issues that arises where acquisition accounting is carried out is that, in most acquisitions, there is a difference between the price paid for the business and the value of the net assets acquired. This difference is known as goodwill, and accounting for it has occupied the minds of standard setters and preparers for decades. If it is treated as an asset and amortised, it can have a significant effect in depressing reported profits. An alternative accounting treatment involves treating goodwill as an asset, but not subjecting it to regular amortisation. Instead, the asset would be regularly tested for so-called 'impairment', that is, tested to see if its value has reduced. Only if it can be proved that it has lost value, would there be any effect on profit. 
Initially, FASB proposed to reduce the maximum acceptable period for amortisation of goodwill from 40 years to 20 years (which would mean that many businesses would have to set higher amounts of amortisation against their profits, thus reducing reported earnings and earnings per share). Strange to relate, during the course of discussions and hearings FASB's view changed, and the Board decided to take a non-amortisation approach to goodwill. In FASB's annual report the chairman reported this highly significant change in neutral terms: "Rather than have companies write off goodwill against earnings for up to 20 years as originally proposed, after thorough analysis we concluded that it would be more appropriate to test goodwill for impairment" (Financial Accounting Foundation, 2000) This was clearly a politically motivated concession to its critics. One of the principal reasons for fearing curtailment to the use of pooling was the obligation under the purchase method to account for goodwill and to take an earnings hit (albeit over a period of up to 20 years under the new proposals ${ }^{\mathrm{iv}}$ ). Under the FASB concession earnings will be affected only if there is an impairment in the value of goodwill. Much therefore depends upon the de facto effectiveness of the impairment requirements, but, given that goodwill valuation is such a subjective and difficult area, it seems likely that American corporations will be able to use the requirement as quite an effective way to manage their earnings.

The story behind the issuing of standards 141 and 142 is interesting and instructive. It illustrates the intense political nature of standards setting in the USA (at one stage a bill was presented to Congress to place a moratorium on FASB's ability to eliminate the pooling method of accounting ${ }^{\mathrm{v}}$ ). In order to be able to introduce the standard eliminating pooling FASB had to make a major concession by removing the requirement to amortise goodwill, thus creating an opportunity for some creative earnings management at the individual company level. It appears that the principal consequential outcome informing its action in this respect was the threat to its own survival as a standard setter.

\section{Creative accounting in Spain: a case of micro-manipulation}

As noted earlier in the paper, where strict application of the rules does not produce an accounting result that meets the needs of preparers, there is an incentive to misapply or to 
ignore the rule. Creative accounting (also known as income smoothing, earnings management, cosmetic accounting or financial engineering) has been variously defined as:

"...the deliberate dampening of fluctuations about some level of earning considered to be normal for the firm". (Barnea et al. 1976)

“....any action on the part of management which affects reported income and which provides no true economic advantage to the organization and may, in fact, in the long-term, be detrimental". (Merchant and Rockness, 1994)

“...[involving] the repetitive selection of accounting measurement or reporting rules in a particular pattern, the effect of which is to report a stream of income with a smaller variation from trend than would otherwise have appeared". (Copeland, 1968).

Many research studies have tended towards the conclusion that creative accounting does exist (e.g. McNichols and Wilson, 1988; Barnea et al., 1976; Dempsey et al., 1993; Dascher and Malcolm, 1970). However, there is also evidence to suggest that investors do not necessarily see through creative accounting (for example, Healy and Wahlen, 1999, cite studies that find that creative accounting prior to equity issues does affect share prices). Also, there is some evidence that even quite clear signalling can be misinterpreted or ignored even by relatively sophisticated users (Breton and Taffler, 1995). Furthermore, Dechow and Skinner (2000) argue that even if financial statement provide sufficient information to permit users to adjust for creative accounting, there would still be cause for concern because certain categories of investors have limited ability to process the information available in the notes to the financial statements.

Amat et al. (2003) report a study identifying a set of quite overt creative accounting practices in some of the IBEX-35, stockmarket index which includes the 35 largest listed companies in Spain. The following occurrences were classified for the purposes of the study as possible indicators of creative accounting (in that they alter the impression presented to users by the financial statements): 
?? Auditor report qualifications (in Spain, there is no requirement to restate the financial statements to reflect the effects of qualifications, although the effect is noted in the auditor's report. This means that the view given by the financial statements can be, at least superficially, misleading);

?? Special authorisations from regulatory agencies to adopt non-standard accounting policies (this is a peculiarity of the Spanish accounting environment ${ }^{\mathrm{vi}}$ );

?? Changes in accounting policy from one year to another (these are relatively common in Spain. The effects of such changes have to be quantified and explained in the auditor's report).

The impact of these factors was assessed for each of the three financial years in the 19992001 period. The aggregate impact on earnings of these practices amounted to $20 \%$ of total reported earnings. Table 1 summarises the findings: 


\begin{tabular}{llll}
\hline & $\mathbf{1 9 9 9}$ & $\mathbf{2 0 0 0}$ & $\mathbf{2 0 0 1}$ \\
\hline $\begin{array}{l}\text { \% of IBEX-35 companies adopting } \\
\text { more of the three practices }\end{array}$ & $40 \%$ & $45.7 \%$ & $25.7 \%$ \\
Number of companies & 14 & 16 & 9 \\
Reported earnings $>$ adjusted earnings & 5 & 11 & 7 \\
Reported earnings $<$ adjusted earnings & 9 & 5 & 2 \\
\hline
\end{tabular}

Table 1: IBEX-35 companies adopting practices indicative of creative accounting 19992001 (Source: Amat et al. 2003)

It may be noted that in 1999, a year when the economy was in a relatively buoyant condition, the reported earnings of nine firms were less than adjusted earnings. However, in 2000 and 2001 when the Spanish economy was affected by an economic downturn, the position is reversed. This result suggests the possibility that creative presentation of results could be related to general economic conditions (a possibility flagged by Merchant, 1990).

This study has some important implications for the enforceability of international standards. Listed companies in Spain, in common with those in other European countries, will shortly adopt international standards ${ }^{\text {vii }}$. It seems, however, that the peculiarly Spanish approach to implementing accounting regulation will cease. Currently, supervising agencies, notably in the banking sector, may permit companies to adopt an accounting policy that contravenes current accounting regulation. These authorisations are provided as the result of successful lobbying by either a company or representative companies within an industrial sector ${ }^{\text {viii }}$. Successful lobbying of this type illustrates the power and influence that preparers may exert over regulators. It seems highly unlikely that such power relationships will suddenly cease in 2005, and we may expect that Spanish companies will continue with their existing practices as far as it is possible to do so. Because the international accounting regulation is extremely weak in respect of enforcement, any enforcement that exists will rely upon the same national authorities that currently permit relatively slack accounting disclosure in Spain. 


\section{Discussion}

The two kind of behaviors discussed above illustrate different manifestations of the power and influence of preparers of financial statements. What light do these cases shed upon the ethical issues in accounting manipulation that were identified earlier in the paper?

The first case illustrates the relative weakness of the US standard setting body in dealing with a powerful preparer lobby. The contretemps over accounting for goodwill was not the first time that the authority of FASB has been challenged but the lobbying efforts that took place on this occasion were perhaps the most serious challenge that has been made to the authority of a national standard setter. The second case demonstrates that lobbying against regulation can become institutionalised. It is also clear that some significant manipulation of the appearance of major corporations' income statements takes place in other ways too. Regulation in both cases becomes a negotiation between the regulator and the preparer of financial statements. The interests of the users of the statements are likely to be overlooked or ignored in such cases. The overt manipulation robs the regulating body and the regulatory process of respect and authority.

User needs are ignored in the processes of manipulation at both macro- and micro level that we have analysed in the paper. The exercise of power of the preparers is both unjust and unfair to the supposed beneficiaries of the reporting process. The fundamental objective of financial statements is deemed to be the provision of useful information for decision-making, but it appears that accounting regulation is too compromised to fulfil this purpose properly. Rawl's justice as fairness principle would seem to be breached by the activities described in this paper.

If we accept with Solomons (1993) that business life is not exempt from considerations of morality, then we can question the activities of accounts preparers as moral agents. In this respect, their actions are found wanting, and they cannot be defended except in the light of the rather dubious and amoral agency theoretical approach. The manipulative behaviours studied above employ no more sophisticated principle than the idea that 'might is right'. Further, it is reasonable to question the validity of activities involved in dressing up financial statements to present an appearance that is not fully justified by the 
underlying economic activity. This type of micro-level creative accounting is informed by an intention to deceive the recipients of financial statements, and can therefore be regarded as morally reprehensible.

\section{Conclusion}

This paper has identified some manipulative behavior on the part of preparers of financial statements, taking into account some important ethical concerns. To achieve this, we have tryed to broaden out the usual definition of creativity in accounting examining two principal categories of behaviour by the preparers of financial statements: macromanipulation and micromanipulation.

At the macromanipulation level, some preparers of financial statements are willing to engage in lobbying in an attempt to sway accounting regulators to produce rules that are advantageous to the interests of preparers. In doing so, they are likely to shift the attention of regulators away from the interests of users of the financial statements.

At the micro-manipulation level, some preparers engage in manipulation at their entities in order to present a biased view of economic reality.

Both categories of behaviour are likely to result in financial statements that may suit the purposes of the preparer but which are less than satisfactory from a user's point of view. From an ethical perspective these manipulations can be regarded as morally reprehensible. They are not fair to users, they involve an unjust exercise of power, and they tend to weaken the authority of the regulators. Where regulation is breached with impunity a diminution of respect for it and its procedures is likely to ensue.

\section{References}

Accounting Standards Review Board [New Zealand]: 2002, Press release, 19 December. Accessed on 8 March 2004 at www.asrb.co.nz

Amat, O., Gowthorpe, C. and Perramon, J.: 2003, 'Earnings management in Spain: an assessment of the effect on reported earnings of larger listed companies 19992001', Economic Working Paper Series, Universitat Pompeu Fabra. 
Ayers, B.C., Lefanowicz, C.E. and Robinson, J.R.: 2000, 'The financial statement effects of eliminating the pooling-of-interests method of acquisition accounting', Accounting Horizons, Vol. 14, No.1, March, pp. 1-19.

Barnea, A., Ronen, J. and Sadan, S.: 1976 'Classificatory smoothing of income with extraordinary items', The Accounting Review, January, pp.110-122.

Breton, G. and Taffler, R.J.: 1995 'Creative accounting and investment analyst response', Accounting and Business Research, Vol. 25, No. 98, pp. 81-92.

Cairns, D.: 2001 'IAS lite is alive and well', Accountancy, May, pp. 88-9.

Cisco: 2000, 'Eliminating the pooling method of accounting standards: a threat to the Internet economy', accessed 18 January 2002 at cisco.com/warp/public/779/govtaffs/archive/fasb.html.

Copeland, R.M.: 1968 'Income smoothing', Journal of Accounting Research, VVI, Supplement, pp.101-116.

Dascher, P.E. and Malcom, R.E.: 1970 'A note on income smoothing in the chemical industry', Journal of Accounting Research, Autumn, pp. 253-259.

Dechow, P.M. and Skinner, D.J.: 2000 'Creative accounting: reconciling the views of accounting academics, practitioners and regulators', Accounting Horizons, Vol. 14, Issue 2, pp. 235-51.

Dempsey, S.J., Hunt, H.G. and Schroeder, N.W.: 1993 'Creative accounting and corporate ownership structure: an examination of extraordinary item reporting', Journal of Business Finance and Accounting, 20(4), June, pp. 479-500.

Fearnley, S. and Macve, R.: 2001, 'Global problems', Accountancy, October, p. 110.

Financial Accounting Foundation: 2000, Annual Report, FAF, Norwalk, CT. (available from the FASB website at fasb.org)

Financial Reporting Council [Australia]: 2002, Bulletin, 3 July, accessed on 8 March 2004 at www.frc.gov.au.

Fischer, M. and Rosenzweig, K.: 1995 'Attitudes of students and accounting practitioners concerning the ethical acceptability of earnings management', Journal of Business Ethics, Vol. 14, pp. 433-44. 
Healy, P.M. and Wahlen, J.M.: 1999 'A review of the creative accounting literature and its implications for standard setting', Accounting Horizons, Vol. 13, No. 4, pp. 36583.

Lyons, D.: 1984 Ethics and the rule of law, Cambridge University Press.

McNichols, M. and Wilson, G.P.: 1988 'Evidence of creative accounting from the provision for bad debts', Journal of Accounting Research, Vol. 26, Supplement, pp.1-33.

Merchant, K.A.: 1990, 'The effects of financial controls on data manipulation and management myopia', Accounting, Organizations and Society, Vol. 15, No. 4, pp. 297-313.

Merchant, K.A. and Rockness, J.: 1994 'The ethics of managing earnings: an empirical investigation', Journal of Accounting and Public Policy, 13, pp.79-94.

Naser, K. and Pendlebury, M.: 1992 'A note on the use of creative accounting', British Accounting Review, Vol. 24, pp. 111-118.

Rawl, J.: 1972 A theory of justice, Oxford University Press.

Revsine, L.: 1991 'The selective financial misrepresentation hypothesis', Accounting Horizons, December, pp. 16-27.

Schipper, K.: 2000 'Accounting research and the potential use of international accounting standards for cross -border securities listings', The British Accounting Review, Vol. 32, pp. 243-256.

Solomons, R.C.: 1993 'Corporate roles, personal virtues: an Aristotelian approach to business ethics', in E.R. Winkler and J.R. Coombs (eds), Applied ethics: a reader (Blackwell Publishers, Cambridge, Mass. and Oxford, UK), pp. 201-221.

Zeff, S.A.: 1978 'The rise of "economic consequences", The Journal of Accountancy, December, pp. 56-63.

\section{Notes}

\footnotetext{
${ }^{\mathrm{i}}$ The predecessor body, the IASC, issued 41 standards over a period of almost thirty years. So far, the IASB has issued (at the time of writing) two IFRSs.

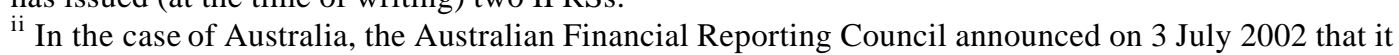
would recommend that from 1 January 2005 the accounting standards applicable to companies would be those issued by the IASB (FRC, 2002). In New Zealand the Accounting Standards Review Board has
} 
recommended to the government that IFRSs should be adopted by entities in both the public and private sectors from 1 January 2007, with the option to adopt as early as 1 January 2005 (ASRB, 2002).

iii Subsequent events in the new technology market proved that several of these predicted consequences could occur without the assistance of FASB.

${ }^{\text {iv }}$ A proposal which would have ensured convergence with the UK's IFRS 10 and the IASC's IAS 22.

${ }^{\mathrm{v}}$ A bill introduced by Representatives Dooley and Cox in the $106^{\text {th }}$ congress.

${ }^{v i}$ A peculiarity shared by France.

${ }^{\text {vii }}$ In addition, a decision has been taken by the Spanish government to extend the application of international standards to non-listed companies. In order to effect this change the Spanish Instituto de Contabilidad y Auditoría de Cuentas (ICAC - Spanish Institute of Accounting and Auditing) plans to issue a new Plan General de Contabilidad (PGC - Spanish Accounting Plan) which will be adapted to IFRSs.

${ }^{\text {viii }}$ This provides an interesting example of a hybrid between macro- and micro-manipulation. 